\title{
Analysis of the Evolution of the Number of Fatal Road Accidents in Romania
}

\author{
Lucian Tarnu ${ }^{1}$, and Cristian Deac ${ }^{1, *}$ \\ ${ }^{1}$ Lucian Blaga University of Sibiu, Romania, Department of Industrial Engineering and Management, Emil Cioran str., 4, Sibiu, \\ Romania
}

\begin{abstract}
Fatal car accidents are a major issue of concern for both the police, the local and regional administrations and all those involved in providing road safety. The current paper presents an analysis of the number of fatal car accidents on Romanian roads, in the context of the Road Safety Programme of the European Commission, emphasising the efforts being made in this regard, the areas where road safety is still lacking and recommending some measures for improving the situation.
\end{abstract}

\section{Introduction}

Nowadays, road traffic has reached in some areas impressive proportions. Unfortunately, the increase of cars driving on roads and motorways has led in many countries and regions also to an increase in the number of car accidents. Fatal car accidents are especially tragic and costly, both in terms of the material losses and in terms of human lives, representing a major problem of the human society.

According to [1] and [2], respectively, at world level, while in 2002 road traffic injuries were the second-mostfrequent cause of death for the age groups 5-14 years and 15-29 years and the third-most frequent cause of death for the age group 30-44 years, in 2012 road traffic injuries were the main cause of death for the age group 15-29 years and it is projected to be ranked $7^{\text {th }}$ among all age groups in 2030.

In the European Union, a first attempt to address this major problem was the setting of a goal to reduce road fatalities on all roads of the Union from 2001 to 2010 by $50 \%$. However, the measures adopted in correlation with this goal were insufficient, so that the achieved reduction level was of only $35 \%$. In 2011 more than 31,500 people lost their lives in the European Union due to car accidents (figure $1[3]$ ).

Consequently, in 2011, the European Commission's White Paper on Transport and the Action Programme on Road Safety have called for a $50 \%$ reduction of the road traffic fatalities in the European Union from 2011 to 2020, aiming towards a rate of zero fatalities from road accidents in 2050 [4].

As can be seen from figure 1, however, there are once more growing discrepancies between the set goal and the achieved reduction in road fatalities.

For its part, Romania has adopted this goal, aiming to reduce road fatalities by half over the period 2011-2020.

In the current paper, the authors analyse the situation of fatal car accidents in Romania at national and county level, compared to the goal set as mentioned above, indicating the main causes identified for these accidents and suggesting a series of measures that would need to be implemented, both at national, regional and local level.

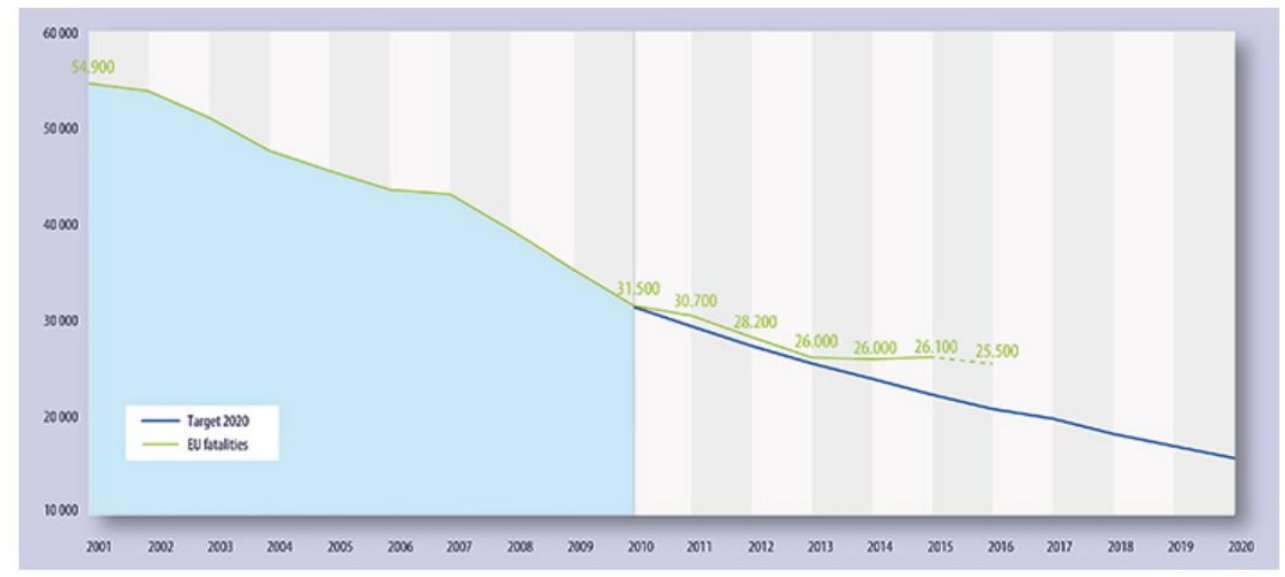

Fig. 1. The number of road fatalities in the EU between 2001 and 2016 compared to the goal set for 2020 [4]

\footnotetext{
* corresponding author: cristian.deac@ulbsibiu.ro
} 


\section{Road Accidents - Considerations and Causes}

Since their invention at the end of the $19^{\text {th }}$ century, cars have gradually transformed and improved human life, they imposed an accelerated rhythm, shortened travel distances and durations and became one of the symbols of modern civilisation [5].

Across the European Union, the number of passenger cars grew by $4.5 \%$ over the last five years, from 241 to 252 million [6].

In Romania, cars first appeared very soon after this means of transportation was invented, more precisely around the year 1890. Currently, there are around 5.7 million cars registered in Romania and more than 6.6 million persons have driver's licenses [5].

Unfortunately, car traffic is sometimes accompanied by accidents, so that cars are sometimes called "lethal weapons". Road accidents are a scourge of the civilised world, that leads each year to important material damage, to minor or major injuries or even the death of participants in the road traffic: car drivers, pedestrians, passengers, bicycle riders, motorcycle riders etc [5]. Statistics at world level show that each year, 1.5 million people die in car accidents, while other 35 million receive severe or light injuries [2].

The consequences of fatal road accidents are even more tragic when taking into account the fact that most victims are young people. An accident-produced death is not only a family tragedy, but a significant loss for the whole society, given the efforts undertaken for the education, professional training and training for life of the young generations [5].

Since many people use road vehicles to commute to the workplace or even to carry out their daily jobs, road traffic accidents can be regarded as work accidents, so risks related to road safety can be determined with a methodology similar to that used for determining the risks at the workplace [7].

Road safety issues have become a major point of interest for many governments and administrative institutions.

Road safety policies have to be devised considering the citizens as major action factors and have to encourage people to take on the responsibility for their own safety and for the safety of the other participants in the road traffic situation.

In the European Union, the goal is to achieve an integrated approach towards the various policies. This means that the road safety policy needs to be closely connected to the policies from areas such as energy, environment, workforce market, education, youth, health, research, development and innovation, justice, insurances, trade etc. The policies in these areas need to take into account the goals of the road safety policy and vice-versa.

The road safety policy of the European Union aims to increase the road safety level so as to allow the safe and ecological movement of citizens on all roads of the member states. It promotes the equality of all road traffic participants, seeking to increase the road safety level for the most vulnerable among them $[8,9]$.
The European Commission considers following three actions as having paramount importance in the area of road safety $[9,10]$ :

- Implementing a structured and coherent cooperation framework based on the best practices in the member countries, as a necessary condition for efficiently implementing the orientations for the European road safety policy 2011-2020;

- Elaborating a strategy regarding injuries and granting first aid, in order to answer the more and more acute need to reduce the number of road accidents leading to injuries.

- Increasing the safety of vulnerable participants in the road traffic, especially with regard to motorcycle riders, in whose case statistics are worrying

The concept of integrated management in the area of road safety and of traffic incidents prevention is used successfully in the member states of the European Union, aiming at the coordination and cooperation of all specialised institutions and authorities, in order to facilitate the achievement of goals set in the area of road safety.

As with all policies of the European Union, the road safety policy too needed to be assumed and implemented by all member states. In Romania, the National Strategy for Road Safety 2016-2020 [11] was drafted and approved as a document containing coherent and unitary long-term policies in the area of road safety, following the unsatisfactory results of the previously valid policies in this area. The strategy presents the main directions for the policy of Romania with regard to road safety, as well as the means for transposing and improving it. This strategy has already been implemented by the institutions and factors involved in the area of road safety, both at national and at local level.

The key actors involved in road safety aspects in Romania are presented in table 1 [12].

Table 1. Key actors in road safety in Romania [12]

\begin{tabular}{|c|c|}
\hline Key functions & Key actors \\
\hline $\begin{array}{l}\text { 1. - Formulation of } \\
\text { national RS strategy } \\
\text { - Setting targets } \\
\text { - Development of the } \\
\text { RS programme }\end{array}$ & $\begin{array}{l}\text { - The Sectoral Operational } \\
\text { Programme "Transport" } \\
\text { - Romanian Road Authority } \\
\text { - Ministry of Transports and } \\
\text { Infrastructure } \\
\text { - Directorate for Road Transport }\end{array}$ \\
\hline $\begin{array}{l}\text { 2. Monitoring of RS } \\
\text { development in the } \\
\text { country }\end{array}$ & - Romanian Road Authority \\
\hline $\begin{array}{l}\text { 3. Improvements in } \\
\text { road infrastructure }\end{array}$ & - Romanian Road Authority \\
\hline $\begin{array}{l}\text { 4. Vehicle } \\
\text { improvement }\end{array}$ & $\begin{array}{l}\text { - Romanian Automotive } \\
\text { Register }\end{array}$ \\
\hline $\begin{array}{l}\text { 5. Improvement in } \\
\text { road user education }\end{array}$ & $\begin{array}{l}\text { - Romanian Road Authority } \\
\text { - Road Traffic Assistance Assoc. }\end{array}$ \\
\hline $\begin{array}{l}\text { 6. Publicity } \\
\text { campaigns }\end{array}$ & - Traffic Police \\
\hline
\end{tabular}




\begin{tabular}{|l|l|}
\hline $\begin{array}{l}\text { 7. Enforcement of } \\
\text { road traffic laws }\end{array}$ & $\begin{array}{l}\text { - The Traffic Police (under } \\
\text { Ministry of Administration and } \\
\text { Interior) }\end{array}$ \\
\hline
\end{tabular}

A road accident in itself does not represent a legal offence, but its causes can be generally traced back to an infringement of the legal provisions related to road safety. The main causes of road accidents in Romania have been identified as follows [5, 8, 9]:

- Excessive speed;

- Not granting the proper passage priority to pedestrians or other vehicles;

- Illegal crossing of the road by pedestrians;

- Carelessness of bicycle and motorcycle riders;

- Insufficient road safety education among the road traffic participants;

- Driving without a valid driver's license;

- Driving under the influence of alcohol Driving

- Driving in a state of advanced tiredness.
In order to improve the situation with regard to the number of fatal car accidents in Romania, there have been taken several measures aimed at fighting the mentioned causes, which led to some progress.

\section{Analysis of the road fatalities situation at national and county level in Romania}

In Romania, the Inspectorate General of the Romanian Police is the authority mandated to collect and manage the data referring to road accidents. It can then transmit the data to the National Statistics Institute and to the interested international institutions.

For their analysis, the authors resorted to data retrieved from the National Registry of Car Accidents [13].

In 2010, statistics indicated the fact that Romania was ranked last in the European Union with regard to road deaths (figure 2, [14]).

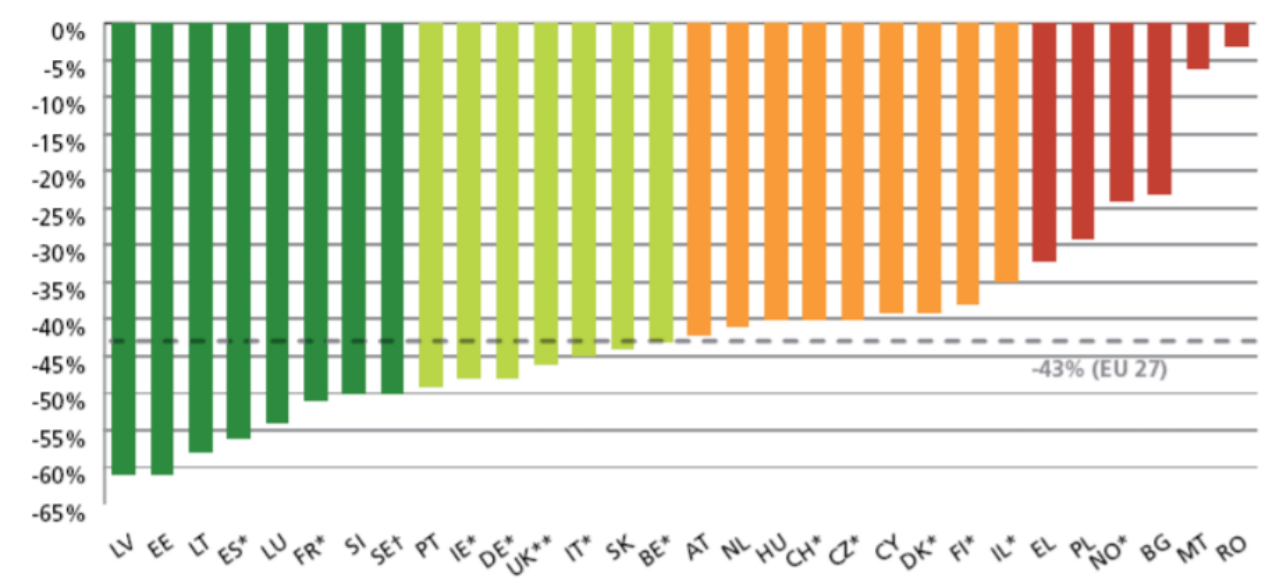

Fig. 2. Status of achievement of the goal of 50\% reduction of road fatalities in 2010 [13].

Since then, especially in the context of the new goalsetting for the period 2011-2020, there has been some progress in Romania towards reaching the European goal of a $50 \%$ reduction in road fatalities.

According to data from the National Registry of Car Accidents [13], the number of fatalities due to car accidents has varied between 2010 and 2017 as shown by the chart presented in figure 2 .

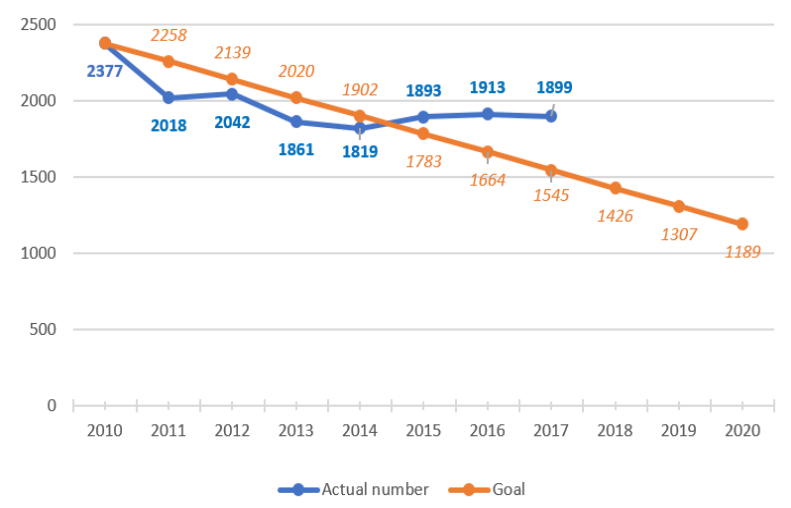

Fig. 3. Number of actual fatalities vs. the goal set for the period 2010-2020 (data from [13])
As shown, despite an initial encouraging reduction in road deaths, the numbers have remained by and large in the same range of values, which should be worrying, given the relatively short time left until the end of the target period (2020).

At county level, the average number of road fatalities per county in the period 2010-2017 was 372. However, there can be noticed a very heterogeneous situation some counties have registered significant improvements in road safety, visible in a steady reduction of road fatalities, while in others the number of road fatalities has remained roughly at the same level since 2010 and in others the number of road fatalities has even increased.

In 19 counties, the number of road fatalities was above the national average, as indicated in figure 3 .

In some of these counties there could be noticed a stagnation or even an increase of the number of road fatalities over the last few years. Figures 5 and 6 present the numbers found in the National Registry of Car Accidents related to the counties of Dolj and Timis.

It should be also mentioned that, while the number of accidents with fatalities on all Romanian motorways represents only a small percentage of the total number of deaths, the number of deaths increased in 2017 to almost twice the number recorded in 2010 (34 versus 18 deaths). 


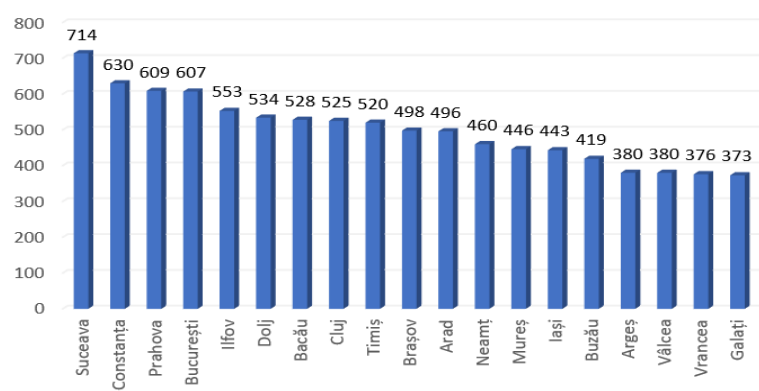

Fig. 4. Counties that recorded a number of fatalities above the national average between 2010 and 2017

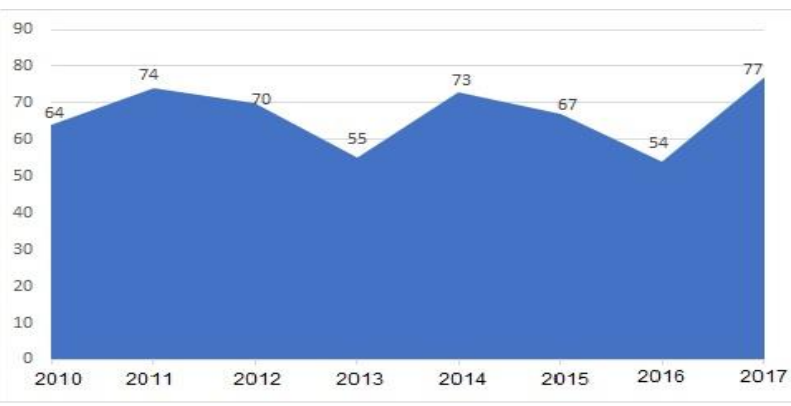

Fig. 5. Evolution of the number of fatal road accidents in the county of Dolj between 2010 and 2017

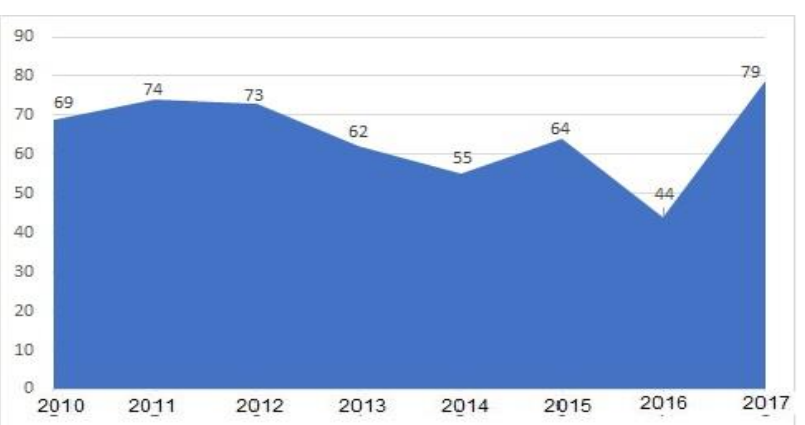

Fig. 6. Evolution of the number of fatal road accidents in the county of Timis between 2010 and 2017

In order to achieve the desired reduction in the number of road deaths, there should be taken some measures, both by the Police and by the other participants in road traffic. Some of these measures could be:

- Periodic checking of the technical status of the vehicles and of the legality of the transportation activities carried out;

- Firm attitude of the policemen towards any infringements of the law on the roads.

- Dissemination of information on road education issues and on road safety campaigns;

- Meetings between road traffic participants on road safety topics

- Improvement of the cooperation between the various actors involved in road works for a better direction of traffic in those areas;

- Implementation of an intelligent road traffic monitoring system

- Improvement of the attitude of passenger car drivers towards pedestrians, public transportation drivers, bicycle and motorcycle riders etc.
While the current values might seem to move the goal for 2020 out of reach, there is still some time left and by implementing the mentioned measures, it is still possible to achieve a reduction of the number of road deaths by $50 \%$ by 2020 in Romania and in the European Union.

\section{Conclusions}

Road safety is an issue of interest for all citizens, each of them being able to contribute to increasing the safety of traffic on public roads.

As the current paper has shown, both at European level and in Romania, there is much to do if the ambitious goal of reducing road fatalities by $50 \%$ in 2020 compared to 2011 is to be achieved. Still, if thoroughly implementing the measures indicated in the paper, the targeted reduction would be still feasible.

In future, the authors intend to extend their researches by applying a questionnaire on road safety to the various categories of participants in the road traffic, especially in the identified problem areas.

\section{References}

1. M. Peden, World report on road traffic injury prevention (World Health Organization, 2004)

2. World Health Organization, Global status report on road safety 2015 (World Health Organization, 2015)

3. European Commission, White Paper on Transport (European Commission, 2011)

4. European Commission, Road Safety: Statistics accidents data (European Commission, 2018)

5. L.I. Tarnu, Analysis, investigation and reconstruction of road accidents (Translated from Romanian), (Editura Universul Juridic, Bucuresti, 2012)

6. ACEA, Vehicles in use 2017 (European Automobile Manufacturers Association, 2017)

7. A. Gligor, Bull. Univ. Ploiesti, LXVI, 4 (2015)

8. L.I. Tarnu, Investigation and reconstruction of road accidents (Translated from Romanian), (Editura Universitatii "Lucian Blaga" din Sibiu, Sibiu, 2009)

9. Inspectorate-General of the Romanian Police, Road Safety Bulletin. Annual Report 2016 (Romanian Police, 2017)

10. L.I. Tarnu, Aspects of the systematisation and signalling of the road traffic in Romania (Translated from Romanian), (Editura Universitatii „Lucian Blaga" din Sibiu, 2016)

11. Government of Romania, Decision 755/2016 on the Approval of the National Strategy for Road Safety 2016-2020 (Official Monitor of Romania, 2016)

12. European Commission, Road Safety Country Overview: Romania (European Commission, 2016)

13. Inspectorate-General of the Romanian Police, National Registry of Road Accidents (Romanian Police, 2017)

14. ETSC, $4^{\text {th }}$ PIN Report: Road Safety Target in Sight: Making up for Lost Time (ETSC, 2010). 